\title{
ACTA
}

PALAEONTOLOGICA

POLONICA

\section{Bringing fossils to life}

David Penney

Acta Palaeontologica Polonica 58 (4), 2013: 836-836 doi: http://dx.doi.org/10.4202/app.2013.1003

Donald R. Prothero 2013. Bringing Fossils to Life: An Introduction to Paleobiology. Third Edition. 672 pp. Columbia University Press, New York. Softcover. ISBN: 978-0-231-15893-0. Price \$95.00/£65.50; Hardcover. ISBN 978-0-231-15892-3. Price \$180.00/£124.00.

David Penney [david.penney@manchester.ac.uk], Faulty of Life Sciences, University of Manchester, Oxford Road, Manchester M13 9PL, UK.

This is an open-access article distributed under the terms of the Creative Commons Attribution License (for details please see creativecommons.org), which permits unrestricted use, distribution, and reproduction in any medium, provided the original author and source are credited.

Faris Full text $(71.2 \mathrm{kB})$ 